Стукаленко В. А., к.ю.н., (Одеський торговельно-економічний інститут Київського національного торговельно-економічного університету), Башинська М. І., к.е.н., (Одеський торговельноекономічний інститут Київського національного торговельноекономічного університету), Сворська М. К., здобувач (Національний університет водного господарства та природокористування, м. Рівне) Кабанова А. $\boldsymbol{\epsilon}$., магістрант (Одеський торговельно-економічний інститут Київського національного торговельно-економічного університету)

\title{
ВПЛИВ ПОДАТКОВОЇ ПОЛІТИКИ НА ФОРМУВАННЯ ПОКАЗНИКІВ ДОХОДІВ ДЕРЖАВНОГО БЮДЖЕТУ УКРАЇНИ
}

У статті досліджено сучасні теоретичні підходи до визначення поняття «податкова політика». 3'ясовано сутність і роль податкової політики в сучасних умовах та розглянуто податкову політику як засіб впливу на розвиток держави. Проаналізовано структуру доходів державного бюджету України з 2014 року по 2017 рік і визначено основні тенденції у формуванні доходів бюджету. Зазначено, що сьогодні серед науковців та практиків немає єдиного бачення ролі у формуванні доходів та видатків Державного бюджету України за допомогою податкової політики, що суттєво ускладнює розробку дієвих механізмів формування доходів Державного бюджету України. Наукова невизначеність поняття «податкова політика» ускладнює виконання державою своїх завдань, функцій, регулювання соціально-економічного розвитку суспільства та створення оптимальних умов для розвитку ефективного економічного середовища.

Ключові слова: податкова політика, Державний бюджет, доходи, податкові надходження.

Постановка проблеми. Акцентування уваги на дослідженні проблематики впливу податкової політики на формування доходів Державного бюджету України пов'язано із багатьма чинниками.

По-перше, саме Державний бюджет характеризує рівень економічного розвитку країни. Виважена політика може стимулювати прискорення без інфляційного зростання обсягів виробництва як на поточний період, так і в довгостроковій перспективі, а також здійснювати коригування основних макроекономічних пропорцій залежно від напрямів загальної економічної політики [1]. 
По-друге, здійснення ефективного бюджетного процесу забезпечує економічну і соціальну стабільність. Наприклад, недосконалість податкової системи, високий податковий тиск змушує учасників відносин приховувати свої доходи, що негативно впливає як на стан публічних фінансів, так і на реальний сектор економіки, пригнічує процеси економічного відтворення за рахунок гальмування підприємницьких ініціатив й діяльності та сприяє виснаженню податкоспроможності платників. І, як наслідок, стагнація економічного розвитку.

По-третє, збалансований стан дохідної та видаткової частин Державного бюджету України впливає, певною мірою, на належний життєвий рівень населення. Це пов'язано із тим, що податкова політика багато в чому, впливає на вибір механізмів формування та виконання Державного бюджету із урахуванням потреб сьогодення та коротко- й довгострокових перспектив, впливає на розвиток національної економіки, зокрема економічне зростання, за рахунок створення дієвих механізмів утримання інфляції, забезпечення гарантій зайнятості населення, формування стійких механізмів отримання належних доходів усіма учасниками господарських відносин та т.п.

Підсилюється актуальність дослідження гострою потребою інтеграції України в Європейський економічний простір, та врахування необхідності розвитку економічної системи в контексті глобалізаційних процесів, відкритої економіки, трансформації зовнішнього та внутрішнього середовища, і тут у нагоді буде узагальнення різноаспектних спостережень науковців щодо сутності, ролі податкової політики в соціально-економічному розвитку країни.

Аналіз останніх досліджень і публікацій. Різні аспекти податкової політики та проблеми, що існують у цій сфері, у своїх працях досліджувало багато науковців, зокрема, Д. Веремчук [4], 0. Загородній [2], О. Петришина [2], А. Крисоватий [1], В. Федосов [3], В. Опарін [3], Г. П'ятаченко [3] та інші.

Невирішена раніше частина загальної проблеми. Рівень теоретичного і методичного осмислення даного питання свідчить про наявність багатьох невирішених питань, що підтверджує відсутність загальноприйнятого підходу до визначення ключових термінів та процедур у сфері податкової політики, їі вплив на формування показників доходів та видатків Державного бюджету України.

Метою роботи $\epsilon$ дослідження теоретичних підходів до визначення поняття «податкова політика», сутності та сутності податкової політики, на основі узагальнення науково-теоретичних напрацювань, обгрунтування їі ролі в соціально-економічному розвитку дер- 
жави та її вплив на формування доходів та видатків Державного бюджету України.

Основні результати дослідження. Податкова політика відіграє в сучасних умовах в Україні важливу роль, у зв'язку із впливом на економічні процеси країни, метою яких $\epsilon$ ефективність соціальноекономічного розвитку. Категорія «податкова політика» $є$ складним соціальним явищем, яке сприяє розв'язанню соціальних потреб суспільства за рахунок створення умов для економічного розвитку української економіки. Завдяки закріпленню податкової політики на законодавчому рівні держава визначає вектор розвитку, а також стратегію і тактику досягнення встановленої мети, тому податкова політика має чітку цілеспрямованість на вирішення конкретних завдань та викликів сьогодення. Так, через податкову політику, яка виступає стратегічним орієнтиром, визначають вектори акумуляції фінансових ресурсів, необхідні державі для виконання своїх функцій, а також здійснюють закріплення напрямків регулювання економіки. Податкова політика виступає підґрунтям для створення ефективного, дієвого механізму, що сприяє зростанню добробуту населення за рахунок створення належного економічного середовища, тому податкове регулювання $€$ одним із інструментів подолання системної фінансово-економічної кризи. Неврахування в практичній діяльності основних засад податкової політики містить у собі загрозу суттєвої економічної дестабілізації.

Необхідно зазначити, що серед науковців відсутнє однозначне розуміння поняття «податкова політика». Також сьогодні серед науковців та практиків немає єдиного бачення ролі державного регулювання економіки, бюджетної системи за допомогою податкової політики.

Можливо виділити три основні концепцій щодо розуміння категорії «податкова політика».

Перша концепція, «вузький підхід», базується на позиції, що сфера застосування податкової політики - лише сфера оподаткування і обмежується встановленням видів податків, платників, об'єктів, ставок, пільг, термінів сплати податків і механізму зарахування їх до бюджету. В межах зазначеного підходу відсутня одностайність.

Перша група дослідників вважає, що податкова політика - це діяльність держави у сфері оподаткування. Наприклад, В. М. Федосов, В. М. Опарін та Г. О. П'ятаченко дають таке визначення податкової політики це: «діяльність держави у сфері встановлення та стягнення податків, зокрема з формування державних доходів за рахунок постійних і тимчасових джерел, встановлення видів податків, 
платежів, об'єктів, ставок, пільг, механізму зарахування» [3].

Інша група дослідників вважає, що це система заходів.

Явним недоліком цієї позиції $€$ те, що, окресливши сферу впливу податкової політики лише сферою оподаткування, автори звужують коло об'єктів та суб'єктів, які підпадають під державне регулювання наслідок реалізації податкової політики.

До прибічників даної концепції можливо віднести таких дослідників як: О. Загородній [2], О. Петришина, В. Опарін, Г. Поляк, Г. П'ятаченко, А. Романов, М. Романовський, А. Толкушкін, В. Федосов [3] та інші.

Другий підхід умовно можна назвати функціонально-цільовим. При цьому підкреслюються функціональні можливості та (або) економічна сутність податків, зазначаються поточні цілі реалізації податкової політики [5]. В межах даного підходу формулювали визначення «податкова політика» такі автори, як І. Александров, О. Василик, Д. Веремчук [4], І. Кучеров, А. Крисоватий, В. Пансков, Н. Мельник та інші.

Наприклад, 0. Василик так визначає дане явище: «це сукупність заходів держави у сфері побудови податкової системи і мобілізації податків до бюджету».

А. Крисоватий наголошує, що «податкова політика - сукупність заходів для встановлення нових і скасування чинних податків та інших обов'язкових платежів до бюджету, зміни ставок, об'єктів оподаткування та об'єктів, що пов'язані з оподаткуванням, податкової бази по податках та інших обов'язкових платежах до бюджету з метою забезпечення фінансових потреб держави на основі дотримання балансу економічних інтересів держави та платників податків» [1].

Д.В. Веремчук запропонував визначати податкову політику держави як сукупність цілеспрямованих заходів держави щодо науково-методичного, нормативно-правового, інституційно-організаційного, інформаційно-аналітичного, ресурсного забезпечення процесів встановлення і стягнення податків та їх адміністрування, що спрямовані на задоволення потреб та інтересів суспільства, а також реалізацію об'єктивних функцій податків з урахуванням впливу факторів внутрішнього середовища і зовнішніх векторів економічної інтеграції [4].

Третій підхід ґрунтується на розумінні податкової політики у широкому сенсі. І, визначенням податкової політики розкривається через розуміння їі як складової частини політики більш високого рівня [6]. В межах цього підходу, вчені по різному підходять до поняття політики вищого рівня. Це може бути політика і фінансова, економіч- 
на; соціально-економічна і т.п.

До недоліків цієї позиції належать намагання розкрити одне поняття за допомогою відсилання на інше поняття, значення якого теж чітко не визначено та науково необґрунтовано. Позитивний момент - акцент на досить високому статусі податкової політики, адже вона $є$ складовою частиною економічної, а в ряді випадків навіть соціально-економічної політики держави.

У рамках даного підходу сформулювали свої визначення В. Ільяшенко, М. Карп, В. Ковальов, Н. Лук'янова, І. Майбуров, Л. Павлова, Д. Черник ті інші. Наприклад, М.В. Карп зазначає: «Податкова політика є складовою частиною загальної фінансової політики держави ... і охоплює такі поняття, як концепція державної діяльності в сфері оподаткування, податковий механізм, а також управління податковою системою держави» [5].

Враховуючи все вищезазначене, можна стверджувати, що формування поняття податкової політики - одна з найактуальніших потреб сьогодення і має здійснюватися шляхом вивчення, аналізу і наукового осмислення у напрямку запровадження такої податкової політики, яка гарантувала б розвиток економіки, сприяла б інтегруванню нашої економіки у міжнародне економічне середовище.

Податкова політика держави є складовою частиною економічної політики, яка базується на сукупності юридичних актів, що встановлюють види податків, зборів та обов'язкових платежів, а також порядок їх стягнення та регулювання.

Податкова політика також являє собою систему заходів із вирішення певних короткострокових та довгострокових завдань, які стоять перед суспільством, за допомогою системи оподаткування.

До довгострокових завдань належать: досягнення економічного розвитку, сприяння формуванню високого рівня зайнятості населення, зростання рівня благополуччя та т.п.

Короткострокові завдання можуть бути різні залежно від потреб. Наприклад, наповнення Державного бюджету України для подальшого перерозподілу державних фінансових ресурсів.

Податкова політика безпосередньо впливає на обсяги доходів Державного бюджету України, тому що виступає важливою складовою комплексу інструментів (разом із бюджетною й монетарною політикою), за допомогою якого відбувається реалізація напрямів і завдань економічної стратегії.

Формування дохідної частини бюджету є важливим видом діяльності будь-якої держави, оскільки для забезпечення виконання своїх функцій держава повинна мати відповідні ресурси.

Прогнозування бюджетних i, зокрема, податкових надходжень - необхідний етап складання державного бюджету. Загальний рі- 
вень доходів та видатків державного бюджету визначається Міністерством фінансів на підставі макроекономічних показників економічного й соціального розвитку України на наступний бюджетний період. Прогноз цих показників складається щорічно відповідно до Закону України «Про державне прогнозування та розроблення програм економічного і соціального розвитку України» від 23.03.2000 р. № 1602-III [7].

Відповідно до ст. 1 Закону України № 1602-III, прогноз економічного і соціального розвитку є засобом обґрунтування вибору тієї чи іншої стратегії та прийняття конкретних рішень державними органами, органами місцевого самоврядування щодо регулювання соціально-економічних процесів та використовується для розроблення Державної програми економічного і соціального розвитку України і для оцінки надходжень і формування показників державного бюджету. Державна програма економічного і соціального розвитку щороку узгоджується з проектом державного бюджету України на відповідний рік [7].

Ефективність податкової політики визначається рівнем надходжень до Державного бюджету України, тобто реалізація податкової політики можлива через Державний бюджет, який є важливим інструментарієм економічного регулювання, макроекономічної стабілізації, антикризового управління, стимулювання економічного розвитку. Наприклад, доходи Державного бюджету України в 2017 році становили 793,564 млрд грн, що на 221,6 млн грн, або 0,02\%, перевищує показники тимчасового плану. Згідно з їі даними, порівняно 3 2016 роком доходи зросли на 192,187 млрд грн, або на 32\% [8].

Державний бюджет розглядається не лише як кошторис надходжень і видатків, але насамперед - як засіб забезпечення макроекономічного збалансування та економічного зростання, фінансовим планом, який, серед іншого, передбачає відтворення умов для власного фінансування у довгостроковому періоді. Інакше кажучи, бюджетні ресурси повинні розглядатися як невід'ємна частина системи суспільного відтворення. Регулююча функція бюджету спирається на фіскальне перенаправлення частини ресурсних потоків у країні відповідно до встановлених законом про Державний бюджет орієнтирів [9]. Здійснення аналізу формування дохідної частини Державного бюджету України дозволяє отримати інформацію щодо детальної оцінки основних джерел надходження, динаміки їх змін, визначення чинників, що призвели до відхилень за кожною статею доходів бюджету та інше. В подальшому, дана інформація дозволяє здійснювати обґрунтування сучасного стану макро- та мікроекономічних показників розвитку економіки України та створювати реалістичні моделі майбутнього розвитку. 
Так, стаття 9 Бюджетного кодексу України визначає структуру доходів - це податкові надходження; неподаткові надходження; доходи від операцій з капіталом; трансферти.

Структура доходів Державного бюджету України за 2014-2017 наведена у табл. 1.

Таблиця 1

Структура доходів Державного бюджету України за 2014-2017 роки

\begin{tabular}{|c|c|c|c|c|c|c|c|c|}
\hline Показники & $\begin{array}{l}2014 \text { р., } \\
\text { грн }\end{array}$ & $\begin{array}{l}2015 \text { p., } \\
\text { грн }\end{array}$ & $\begin{array}{l}2016 \text { p., } \\
\text { грн }\end{array}$ & $\begin{array}{l}2017 \text { p., } \\
\text { грн }\end{array}$ & $\begin{array}{l}2014 \text { p., } \\
\%\end{array}$ & $\begin{array}{l}2015 \mathrm{p} . \\
\%\end{array}$ & $\begin{array}{l}2016 \text { p., } \\
\%\end{array}$ & $\begin{array}{l}2017 \text { p., } \\
\%\end{array}$ \\
\hline Доходи & $\begin{array}{l}354966 \\
\text { млн грн }\end{array}$ & $\begin{array}{l}531551 \\
\text { млн грн }\end{array}$ & $\begin{array}{l}612103 \\
\text { млн грн }\end{array}$ & $\begin{array}{l}787297 \\
\text { млн грн }\end{array}$ & 100 & 100 & 100 & \\
\hline $\begin{array}{l}\text { Податкові } \\
\text { надто- } \\
\text { дження }\end{array}$ & $\begin{array}{l}280178 \\
\text { млн грн }\end{array}$ & $\begin{array}{l}409418 \\
\text { млн грн }\end{array}$ & $\begin{array}{l}503879 \\
\text { млн грн }\end{array}$ & $\begin{array}{l}627154 \\
\text { Млн грн }\end{array}$ & 78.9 & 77.0 & 82.3 & 79.7 \\
\hline $\begin{array}{l}\text { Неподат- } \\
\text { кові над- } \\
\text { ходження }\end{array}$ & $\begin{array}{l}68355 \\
\text { млн грн }\end{array}$ & $\begin{array}{l}120006 \\
\text { млн грн }\end{array}$ & $\begin{array}{l}103635 \\
\text { млн грн }\end{array}$ & $\begin{array}{l}128402 \\
\text { млн грн }\end{array}$ & 19.3 & 22.6 & 16.9 & 16.3 \\
\hline $\begin{array}{l}\text { Інші над- } \\
\text { ходження }\end{array}$ & $\begin{array}{l}6433 \\
\text { млн грн }\end{array}$ & $\begin{array}{l}2127 \\
\text { млн грн }\end{array}$ & $\begin{array}{l}4589 \\
\text { Млн грн } \\
\end{array}$ & \begin{tabular}{|l|}
31741 \\
Млн грн
\end{tabular} & 1.8 & 0.4 & 0.8 & 4.0 \\
\hline
\end{tabular}

Джерело: розроблено авторами за даними [10]

Аналізуючи структуру доходів Державного бюджету, прослідковується стійка тенденція збільшення частки «інших надходжень» в структурі доходів, від 0,4\%( 2015 р.) до 4\% (2017р.) із паралельним зменшенням частки «неподаткових надходжень» - від 22\% (2015р.) до $16,3 \%$ (2017р.). Але, на жаль, тенденція великої частки податкових надходжень в структурі доходів державного бюджету зберігається.

Найбільшу частку, протягом досліджуваного періоду, в доходах бюджету становили податкові надходження, в середньому - 79,2\% (з 2014 р. по 2017 р.), а найменшу - інші надходження, які складають в середньому $1,8 \%$.

Проаналізувавши структуру та динаміку зростання надходжень окремих податкових зборів, бачимо, що найвагомішу частину податкових надходжень до загального фонду держбюджету становлять: ПДВ - 65,5\% (середній показник за 2014-2017 роки) млрд грн; податок на прибуток підприємств - 11,1\% (середній показник за 20142017 роки); акцизний податок - 16,7\% (середній показник за 20142017 роки); ввізне мито - 5,4\% (середній показник за 2014-2017 роки).

Особливе місце серед податкових надходжень займає невід- 
шкодована сума податку на додану вартість. Прослідковується стійка тенденція збільшення обсягу невідшкодованих сум податку на додану вартість. Наприклад, якщо у 2014 році обсяг невідшкодованих сум податку на додану вартість складав 50216 млн грн, то у 2017 році 120061 млн грн, тобто це осяг збільшився на 69845 млн грн. Це сприяє загостренню економічної ситуації в Україні за рахунок збільшення податкового тиску. Так, оптимальний рівень податкового вилучення припускає такий сукупний тягар на осіб, при якому податки не гальмують підприємницьку та інвестиційну діяльність і не знижують життєвий рівень населення, але забезпечують в необхідному об'ємі надходження до бюджету. На жаль, сучасній податковій політиці в Україні не притаманна стимулююча ознака, а яскраво виражена фіскальна спрямованість. Але при такому стані речей гальмується можливість бюджетної системи перерозподіляти ресурси всередині держави, а це негативно впливає на макроекономічну ситуацію в країні.

Таблиця 2

Структура податкових надходжень

Державного бюджету України за 2014-2017 роки

\begin{tabular}{|c|c|c|c|c|c|c|c|c|}
\hline Показники & $\begin{array}{l}2014 \text { p., } \\
\text { грн }\end{array}$ & $\begin{array}{l}2015 \text { p., } \\
\text { грн }\end{array}$ & $\begin{array}{l}2016 \text { p., } \\
\text { грн }\end{array}$ & $\begin{array}{l}2017 \text { p., } \\
\text { грн }\end{array}$ & $\begin{array}{l}\text { 2014p., } \\
\%\end{array}$ & $\begin{array}{l}2015 \text { p., } \\
\%\end{array}$ & $\begin{array}{l}\text { 2016p., } \\
\%\end{array}$ & $\begin{array}{l}\text { 2017p., } \\
\%\end{array}$ \\
\hline 3бір ПДВ & $\begin{array}{l}189241 \\
\text { млн грн }\end{array}$ & $\begin{array}{l}246858 \\
\text { млн грн }\end{array}$ & $\begin{array}{l}329911 \\
\text { млн грн }\end{array}$ & $\begin{array}{l}434041 \\
\text { млн грн }\end{array}$ & 67.5 & 60.3 & 65.5 & 69.2 \\
\hline $\begin{array}{l}\text { Податок на } \\
\text { доходи фізи- } \\
\text { чних осіб }\end{array}$ & $\begin{array}{c}12646 \\
\text { млн грн }\end{array}$ & $\begin{array}{c}55062 \\
\text { млн грн }\end{array}$ & $\begin{array}{c}59810 \\
\text { млн грн }\end{array}$ & $\begin{array}{c}75033 \\
\text { млн грн }\end{array}$ & 4.5 & 11 & 11.9 & 12.0 \\
\hline $\begin{array}{l}\text { Акцизний } \\
\text { податок }\end{array}$ & $\begin{array}{c}44941 \\
\text { млн грн }\end{array}$ & $\begin{array}{c}63111 \\
\text { млн грн }\end{array}$ & $\begin{array}{c}90122 \\
\text { млн грн }\end{array}$ & $\begin{array}{l}108293 \\
\text { млн грн }\end{array}$ & 16.0 & 15.4 & 17.9 & 17.3 \\
\hline $\begin{array}{l}\text { Податок на } \\
\text { прибуток } \\
\text { підприємств }\end{array}$ & $\begin{array}{c}39942 \\
\text { млн грн }\end{array}$ & $\begin{array}{l}34776 \\
\text { млн грн }\end{array}$ & $\begin{array}{c}54344 \\
\text { млн грн }\end{array}$ & $\begin{array}{c}66912 \\
\text { млн грн }\end{array}$ & 14.3 & 8.5 & 10.8 & 10.7 \\
\hline $\begin{array}{l}\text { Плата за ко- } \\
\text { ристування } \\
\text { надрами }\end{array}$ & $\begin{array}{l}18199 \\
\text { млн грн }\end{array}$ & $\begin{array}{c}36990 \\
\text { млн грн }\end{array}$ & $\begin{array}{l}39699 \\
\text { млн грн }\end{array}$ & $\begin{array}{c}43876 \\
\text { млн грн }\end{array}$ & 7.0 & 9.0 & 7.88 & 7.0 \\
\hline Ввізне мито & $\begin{array}{c}12389 \\
\text { млн грн }\end{array}$ & $\begin{array}{c}39881 \\
\text { млн грн }\end{array}$ & $\begin{array}{l}20001 \\
\text { млн грн }\end{array}$ & $\begin{array}{c}23898 \\
\text { млн грн }\end{array}$ & 4.4 & 9.7 & 4 & 3.8 \\
\hline $\begin{array}{l}\text { Відшкоду- } \\
\text { вання } \\
\text { пдВ }\end{array}$ & $\begin{array}{l}\text { - } 50216 \\
\text { млн грн }\end{array}$ & $\begin{array}{l}-68405 \\
\text { млн грн }\end{array}$ & $\begin{array}{l}-94405 \\
\text { млн грн }\end{array}$ & $\begin{array}{l}-120061 \\
\text { млн грн }\end{array}$ & -17.9 & -16.7 & -18.7 & -19.1 \\
\hline інші & $\begin{array}{c}13038 \\
\text { млн грн }\end{array}$ & $\begin{array}{c}11146 \\
\text { млн грн }\end{array}$ & $\begin{array}{c}4396 \\
\text { млн грн }\end{array}$ & $\begin{array}{c}-5535 . \\
\text { млн грн }\end{array}$ & 4.65 & 2.72 & 0.87 & -0.88 \\
\hline \multirow[t]{2}{*}{ Bcboro } & $\begin{array}{l}280178 \\
\text { млн грн }\end{array}$ & $\begin{array}{l}409418 \\
\text { млн грн }\end{array}$ & & $\begin{array}{l}627154 \\
\text { млн грн }\end{array}$ & \multicolumn{4}{|c|}{$\begin{array}{l}\text { \% податкових надходжень } \\
\text { відносно інших джерел дохо- } \\
\text { дів }\end{array}$} \\
\hline & & & & & 78.9 & \begin{tabular}{|l|l}
77.0 \\
\end{tabular} & 82.3 & \begin{tabular}{|l|l}
79.7 \\
\end{tabular} \\
\hline
\end{tabular}

Джерело: розроблено авторами за даними [10] 
Аналіз доходів Державного бюджету по статтям і в динаміці дозволяє скорегувати основні засади податкової політики держави за рахунок визначення економічних чинників, що впливають на надходження за кожною статею доходів, а особливо податкових надходжень, для того, щоб прослідкувати взаємозв'язки в бюджетній системі України та виявити інструменти впливу на окремі елементи, які забезпечують формування доходів Державного бюджету. Від правильного вибору інструментів податкової політики напряму залежить праксиологічне функціонування бюджетної та економічної систем в цілому та окремих їх складових. Це пов'язано із тим, що провідна роль у мобілізації бюджетних ресурсів, формуванні доходів та їх використання належить податковій політиці, бо вона націлена на формування та розподіл бюджетних ресурсів, з метою забезпечення ефективного управління фінансовими ресурсами. У зв'язку із цим, податкова політика виступає важливим інструментарієм держави для досягнення першочергових економічних цілей, таких як економічне зростання, збалансування бюджетної системи, зниження податкового тиску та т.п.

Висновки. Наукове осмислення категорії «податкова політика» дозволяє обґрунтувати оптимальні напрями реформування податкової політики із урахуванням реалій сьогодення. Слід зазначити, що розвиток економічної системи в площині глобалізаційних процесів та євроінтеграції, постійної зміни умов зовнішнього та внутрішнього економічного середовища потребує постійного перегляду інструментів та методів, націлених на забезпечення дієвості податкової політики.

Податкова політика - це діяльність держави у сфері встановлення і стягнення податків та зборів. Головними чинниками, які оцінюють дієвість податкової політики, є економічна ефективність і рівень інвестиційної привабливості, а також рівень добробуту населення. Враховуючи це, одним із ключових завдань податкової політики України в сучасних умовах $€$ формування такої податкової системи, яка буде орієнтована на економічне зростання за рахунок створення умов для макроекономічної стабільності та формування збалансованого Державного бюджету України.

Ефективність податкової політики реалізується через Державний бюджет. У зв'язку із цим, дуже важливо правильно оцінювати показники доходів та видатків, що дозволить виявити потенціал для їх збалансування. Ігнорування стану та динаміки показників бюджету при розробці податкової політики означає відмову від використання одного з найпотужніших і потенційно ефективних інструментів 
іï реалізації. Аналіз виконання бюджету за доходами та видатками наповнить процес розробки стратегії новим імпульсом і буде сприяти закріпленню певних стимулів для подальшого розвитку економічного потенціалу держави із урахуванням реалій сьогодення.

1. Крисоватий А. І. Теоретико-організаційні домінанти та практика реалізації податкової політики в URL: http://dspace.tneu.edu.ua/bitstream/316497/24549/1/Теоретикоорганізаційні\%20домінанти.pdf (дата звернення: 10.10.2018). 2. Загородній О. М., Петришина О. В. Теоретичні аспекти поняття «податкова політика» та принципи іï ефективного впровадження. URL: http://intkonf.org/zagorodniy-om-petrishina-ov-teoretichni-aspektiponyattya-podatkova-politika-ta-printsipi-yiyi-efektivnogo-vprovadzhennya (дата звернення: 10.10.2018). 3. Податкова система України : підручник / Федосов $\quad$ В.M. та ін. URL: https: // http://kneu.edu.ua/ua/science_kneu/scientific_schools/spf/spf_praci/spf_pra zi/podsysukr (дата звернення: 10.10.2018). 4. Веремчук Д. В. Трансформація податкової політики України в умовах інтеграційних процесів. URL: http://uabs.edu.ua/images/stories/sc_autoref/2012/2012_03_ken.pdf (дата звернення: 10.10.2018). 5. Веремчук Д. В. Сутність податкової політики та її роль у державному регулюванні економіки. URL: // http: //essuir.sumdu.edu.ua/bitstream/123456789/54389/5/Veremchuk_Sutnist.pd f (дата звернення: 10.10.2018). 6. Податкова політика: теорія, методологія, інструментарій.

URL: https://pns.hneu.edu.ua/mod/resource/view.php?id=61100 (дата звернення: 10.10.2018). 7. Про державне прогнозування та розроблення програм економічного і соціального розвитку України : Закон України від 23.03.2000 р. № 1602-III. URL: http://zakon.rada.gov.ua/laws/show/1602-14 (дата звернення: 10.10.2018). 8. Держбюджет-2017 виконано за доходами на 100\%. URL: https://ua.interfax.com.ua/news/economic/474484.html (дата звернення: 10.10.2018). 9. Жаліло Я. А. Економічна стратегія держави: теорія, методологія, практика : монографія. Київ : НICД, 2003. 368 с. URL: http:// politics.ellib.org.ua/pages-4011.html (дата звернення: 10.10.2018). 10. Доходи бюджету. URL: http://cost.ua/budget/revenue/ (дата звернення: 10.10.2018).

\section{REFERENCES :}

1. Krysovatyi A. I. Teoretyko-orhanizatsiini dominanty ta praktyka realizatsii podatkovoi polityky $v$ Ukraini. URL: http://dspace.tneu.edu.ua/ bitstream/316497/24549/1/Teoretyko-orhanizatsiini\%20dominanty.pdf (data zvernennia: 10.10.2018). 2. Zahorodnii 0. M., Petryshyna 0. V. Teoretychni aspekty poniattia «podatkova polityka» ta pryntsypy yii efektyvnoho vprovadzhennia. URL: http://intkonf.org/zagorodniy-om-petrishina-ovteoretichni-aspekti-ponyattya-podatkova-politika-ta-printsipi-yiyi-efektivnogo- 
vprovadzhennya (data zvernennia: 10.10.2018). 3. Podatkova systema Ukrainy : pidruchnyk / Fedosov V. M. ta in. URL: https: // http://kneu.edu.ua/ua/science_kneu/scientific_schools/spf/spf_praci/spf_pra zi/podsysukr (data zvernennia: 10.10.2018). 4. Veremchuk D. V. Transformatsiia podatkovoi polityky Ukrainy $v$ umovakh intehratsiinykh protsesiv.

URL:

http://uabs.edu.ua/images/stories/sc_autoref/2012/2012_03_ken.pdf (data zvernennia: 10.10.2018). 5. Veremchuk D. V. Sutnist podatkovoi polityky ta yii rol u derzhavnomu rehuliuvanni ekonomiky. URL: // http: //essuir.sumdu.edu.ua/bitstream/123456789/54389/5/Veremchuk_Sutnist.pd f (data zvernennia: 10.10.2018). 6. Podatkova polityka: teoriia, metodolohiia, instrumentarii.

URL:

https://pns.hneu.edu.ua/mod/resource/view.php?id=61100 (data zvernennia: 10.10.2018). 7. Pro derzhavne prohnozuvannia ta rozroblennia prohram ekonomichnoho i sotsialnoho rozvytku Ukrainy : Zakon Ukrainy vid 23.03.2000 r. № 1602-III. URL: http://zakon.rada.gov.ua/laws/show/1602-14 (data zvernennia: 10.10.2018). 8. Derzhbiudzhet-2017 vykonano za dokhodamy na 100\%. URL: https://ua.interfax.com.ua/news/economic/474484.html (data zvernennia: 10.10.2018). 9. Zhalilo Ya. A. Ekonomichna stratehiia derzhavy: teoriia, metodolohiia, praktyka : monohrafiia. Kyiv : NISD, 2003. 368 s. URL: http:// politics.ellib.org.ua/pages-4011.html (data zvernennia: 10.10.2018). 10. Dokhody biudzhetu. URL: http://cost.ua/budget/revenue/ (data zvernennia : 10.10.2018).

Рецензент: д.е.н., професор Савіна Н. Б. (НУВГП)

Stukalenko V. A., Candidate of Juridical Sciences (Odessa Trade and Economic Institute of the Kiev National Trade and Economic University), Bashynska M. I., Candidate of Economics (Ph.D.) (Odessa Trade and Economic Institute of the Kiev National Trade and Economic University), Svorska M. K., Applicant (National University of Water and Environmental Engineering, Rivne), Kabanova A. Y., Graduate Student (Odessa Trade and Economic Institute of Kyiv National Trade-Economic University)

\section{INFLUENCE OF TAX POLICY ON THE FORMATION OF INDICATORS OF THE STATE BUDGET INCOME OF UKRAINE}

The article examines modern theoretical approaches to the definition of the concept of «tax policy». The essence, the role of tax policy in modern conditions is clarified, and tax policy is considered as an instrument of influence on the development of the state. The structure of revenues of the state budget of Ukraine from 2014 to 2017 is analyzed and the main trends in the formation of budget revenues are revealed. It was noted that today among scientists and practitioners there is no common vision of the role of tax policy in the 
formation of income and expenditure of the State Budget of Ukraine, which makes it difficult to develop effective mechanisms for generating income of the State Budget of Ukraine. The scientific ambiguity of the concept of «tax policy» « makes it difficult for the state to fulfill its tasks and functions, complicates the regulation of the socio-economic development of society and creates a favorable climate for the development of an effective economic environmen. Keywords: tax policy, state budget, revenues, tax revenues.

Стукаленко В. А., к.ю.н., (Одесский торгово-экономический інститут Киевского национального торгово-экономического университета), Башинська М. В., к.е.н., (Одесский торгово-экономический інститут Киевского национального торгово-экономического университета), Сворская М. К., соискатель (Национальный университет водного хозяйства и природопользования, г. Ровно), Кабанова А. Е., магистрант (Одесский торгово-экономический институт Киевского национального торгово-экономического университета)

\section{ВЛИЯНИЕ НАЛОГОВОЙ ПОЛИТИКИ НА ФОРМИРОВАНИЕ ПОКАЗАТЕЛЕЙ ДОХОДОВ ГОСУДАРСТВЕННОГО БЮДЖЕТА УКРАИНЫ}

В статье исследованы современные теоретические подходы к определению понятия «налоговая политика». Выяснено сущность, роль налоговой политики в современных условиях, а налоговая политика рассмотрена как инструмент влияния на развитие государства. Проанализирована структура доходов государственного бюджета Украины с 2014 года по 2017 год и выявлены основные тенденции в формировании доходов бюджета. Отмечено, что сегодня среди ученых и практиков нет единого видения роли налоговой политики в формировании доходов и расходов Государственного бюджета Украины, что существенно затрудняет разработку действенных механизмов формирования доходов Государственного бюджета Украины. Научная неопределенность понятия «налоговая политика» затрудняет выполнение государством своих задач, функций, усложняет регулирование социально-экономического развития общества и термозит создание оптимальных условий для развития эффективной экономической среды.

Ключевые слова: налоговая политика, государственный бюджет, доходы, налоговые поступления. 